\title{
Author Correction: ArchR is a scalable software package for integrative single-cell chromatin accessibility analysis
}

Jeffrey M. Granja (D), M. Ryan Corces, Sarah E. Pierce, S. Tansu Bagdatli, Hani Choudhry, Howard Y. Chang (D) and William J. Greenleaf(D)

Correction to: Nature Genetics https://doi.org/10.1038/s41588-021-00790-6, published nline 25 February 2021.

This paper was originally published without open access. As of the date of this correction, the paper is available online as an open-access paper under a Creative Commons Attribution 4.0 International License. The Acknowledgements have additionally been updated to specify the funding agency for NCI Cancer Moonshot grant U2CCA233311.

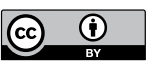

Open Access This article is licensed under a Creative Commons Attribution 4.0 International License, which permits use, sharing, adaptation, distribution and reproduction in any medium or format, as long as you give appropriate credit to the original author(s) and the source, provide a link to the Creative Commons license, and indicate if changes were made. The images or other third party material in this article are included in the article's Creative Commons license, unless indicated otherwise in a credit line to the material. If material is not included in the article's Creative Commons license and your intended use is not permitted by statutory regulation or exceeds the permitted use, you will need to obtain permission directly from the copyright holder. To view a copy of this license, visit http://creativecommons.org/licenses/
\end{abstract} by $/ 4.0 \%$.

Published online: 31 March 2021

https://doi.org/10.1038/s41588-021-00850-x

(C) The Author(s) 2021

\section{Author Correction: The $\mathrm{NCl}$ Genomic Data Commons}

Allison P. Heath (D), Vincent Ferretti, Stuti Agrawal (D), Maksim An, James C. Angelakos, Renuka Arya, Rosita Bajari, Bilal Baqar, Justin H. B. Barnowski, Jeffrey Burt, Ann Catton, Brandon F. Chan, Fay Chu, Kim Cullion, Tanja Davidsen, Phuong-My Do, Christian Dompierre, Martin L. Ferguson (D), Michael S. Fitzsimons (D), Michael Ford, Miyuki Fukuma, Sharon Gaheen, Gajanan L. Ganji D, Tzintzuni I. Garcia, Sameera S. George, Daniela S. Gerhard, Francois Gerthoffert, Fauzi Gomez, Kang Han, Kyle M. Hernandez, Biju Issac D, Richard Jackson, Mark A. Jensen, Sid Joshi, Ajinkya Kadam, Aishmit Khurana, Kyle M. J. Kim, Victoria E. Kraft, Shenglai Li, Tara M. Lichtenberg, Janice Lodato, Laxmi Lolla, Plamen Martinov, Jeffrey A. Mazzone, Daniel P. Miller (D), Ian Miller, Joshua S. Miller, Koji Miyauchi, Mark W. Murphy, Thomas Nullet, Rowland O. Ogwara, Francisco M. Ortuño (D), Jesús Pedrosa, Phuong L. Pham, Maxim Y. Popov, James J. Porter, Raymond Powell, Karl Rademacher, Colin P. Reid, Samantha Rich, Bessie Rogel, Himanso Sahni, Jeremiah H. Savage (D), Kyle A. Schmitt, Trevar J. Simmons, Joseph Sislow, Jonathan Spring, Lincoln Stein, Sean Sullivan, Yajing Tang, Mathangi Thiagarajan, Heather D. Troyer, Chang Wang, Zhining Wang Di, Bedford L. West, Alex Wilmer, Shane Wilson, Kaman Wu, William P. Wysocki, Linda Xiang D, Joseph T. Yamada, Liming Yang, Christine Yu, Christina K. Yung (D), Jean Claude Zenklusen, Junjun Zhang (D), Zhenyu Zhang, Yuanheng Zhao, Ariz Zubair (D), Louis M. Staudt and Robert L. Grossman (D)

Correction to: Nature Genetics https://doi.org/10.1038/s41588-021-00791-5, published online 22 February 2021.

In the version of this article initially published, in the Author contributions, J.Z. was not included as a contributor to bioinformatics, data curation and data modeling. The error has been corrected in the HTML and PDF versions of the article.

Published online: 18 May 2021

https://doi.org/10.1038/s41588-021-00883-2

(c) Springer Nature America, Inc. 2021 